\title{
Intentional replantation with preapplication of orthodontic force on mandibular second molar
}

\author{
Jong-Soon Kim, Hoon-Sang Chang, Yun-Chan Hwang, In-Nam Hwang, Won-Mann Oh*, Bin-Na Lee* \\ Department of Conservative Dentistry, School of Dentistry, Dental Science Research Institute, Chonnam National University, \\ Gwangju, Republic of Korea
}

Intentional replantation has been used for alternative treatment for conventional root canal therapy. This case report describes that the intentional replantation with application of extrusive orhodontic force for 6 weeks, on which tooth of previous root canal therapy. As preapplicatory orthodontic force, tooth moblity was increased so that extraction of the designated tooth was more easily accomplished and augmented volume of periodontal ligament is expected to acceleated gingival reattachment. (J Dent Rehabil Appl Sci 2021;37(4):274-80)

Key words: orthodontic force; intentional replantation

\section{서론}

의도적 재식술은 치아의 의도적 발치 후 치근의 평가, 처치 및 치근단 폐쇄 후 즉각적인 재식립하는 술식으로 Grossman 이후 다양한 학자들에 의해 정의된 바 있다. ${ }^{1}$ 종종 의도적 재식술은 치아를 보존하기 위한 최후의 수 단으로 여겨진다. ${ }^{2}$ 의도적 재식술은 개원가에서 흔히 시 행되는 술식은 아니며 여러 보고에서 그 성공율은 다양 하게 나타났다. ${ }^{1,3,4}$ 비록 제한 적인 증례에서 만이기는 하 나 의도적 재식술이 가이드라인에 따라 잘 시행되었을 경우 성공율은 최대 $95 \%$ 로 보고되었다. ${ }^{5-8}$

의도적 재식술은 통상적인 치근단 수술에 비해 다음과 같은 장점이 있다. 신경과 혈관 등 주변 구조물에 덜 침습 적이며, 더 확실한 치근단 폐쇄가 가능하다. 또한 환자의

\footnotetext{
${ }^{*}$ Correspondence to: Bin-Na Lee

Associated Professor, Department of Conservative Dentistry, School of Dentistry, Chonnam National University, Youngbong-ro 77, Buk-gu, Gwangju, 61186, Republic of Korea

Tel: +82-62-530-5868, Fax: +82-62-530-5629, E-mail: bnlee13@jnu.ac.kr *Correspondence to: Won-Mann Oh

Professor, Department of Conservative Dentistry, School of Dentistry, Chonnam National University, Youngbong-ro 77, Buk-gu, Gwangju, 61186, Republic of Korea Tel: +82-62-530-5572, Fax: +82-62-530-5629, E-mail: wmoh@jnu.ac.kr Received: September 15, 2021/Last Revision: November 2, 2021/Accepted: November 12, 2021

*Bin-Na Lee and Won-Mann Oh contributed equally to this work as corresponding authors.
}

술후 불편감이 적고 육안으로 직접 crack이나 fissure 등 을 확인할 수 있어 정확한 진단이 가능하다. 반면 단점으 로는 발치시 치아의 파절 가능성이 있으며 술후 합병증 으로 치근 흡수 또는 유착의 가능성이 있다는 것이다. 또 한 고정성 보철물 등의 보철물은 제거해야 술식 적용이 가능하다. ${ }^{4}$ 다만, 의도적 재식술을 하는 치아는 치주 질 환으로 인한 심한 동요도를 갖는 치아나 협측 피질골의 심한 파괴나 흡수 또는 수복이 불가능할 정도의 치질 파 괴가 있는 경우에는 시행하지 않아야 한다. ${ }^{9}$

치주인대는 혈관이 풍부한 세포성 결합 조직으로서 치 조골과 치아사이에 위치하며 치의 지지, 부착, 감각 기능 을 제공하는 역할을 한다. ${ }^{10}$ 치주인대의 일차적인 기능은 치근을 치조골에 부착시키며 저작력과 같은 기계적 자극 을 여러 방향으로 분산 시키는 것으로서 치주인대가 일

Copyright@ 2021 The Korean Academy of Stomatognathic Function and Occlusion. (c) It is identical to Creative Commons Non-Commercial License. 
종의 충격-흡수 시스템 기능을 한다. ${ }^{11}$ 치주인대의 가장 흥미로운 특성 중 하나는 급격하게 가해지는 힘에 적응 하며 스스로 치유와 재생이 가능 하다는 것이다. ${ }^{10}$ 치근 표면에 부착되어 유지되는 치주인대는 치아 재식 이후에 도 새로운 치주인대를 재생할 수 있는 능력이 있다. ${ }^{12}$ 게 다가 재식된 치아의 치주인대는 골생성을 유도하는 능 력이 있는데 치주인대 세포가 유전적으로 재식된 치아의 주변에서 골모세포로 분화 할 수 있기 때문이다. ${ }^{13}$ 몇몇 동물 연구를 통한 연구 결과에서 사전적 교정력을 가하 여 치주인대 폭경을 증가시켜 발치를 용이하게 하며 발 치 과정 동안 치주인대의 손상을 최소화 시킬 수 있었다 는 보고를 한바 있다. ${ }^{14,15}$

본 저자는 의도적 재식술을 시행하기 전 사전적 정출성 교정력을 가한 후 성공적으로 의도적 재식술을 시행한 증례에 대해서 소개하고자 한다.

\section{증례보고}

35 세 여자 환자가 몇 년 전 왼쪽 아래 어금니의 근관 치 료를 받았는데 해당 치아에 가끔씩 통증이 발생한다는 것을 주소로 내원하였다. 임상 검사 및 방사선 검사 상 좌 측 하악 제 2 대구치에 근관치료가 되어 있었으며 원심 치 근에 식립된 파이버 포스트의 단면이 레진 코어와 함께 노출된 채로 유지되고 있었다. 치근단 방사선 사진상 방 사선투과성 병소가 확인되었고 타진에 대한 통증을 호소 하였으며 동요도는 없었고 설측 치은의 미약한 부종 및
발적이 확인되었다(Fig. 1).

이에 따라 좌측 하악 제 2 대구치에 대해 동이 없는 근 단주위농양으로 진단을 내렸다. 해당 치아는 파이버 포 스트가 수복되어 있어 재근관 치료가 어려웠으며, 치근 단 수술을 하기에는 해부학적으로 치근단이 하치조신경 과 근접해 있어 의도적 재식술을 계획하였다. 구강내 노 출된 치질의 양이 적고 코어로만 수복된 상태여서 치아의 파절 가능성을 줄이기 위해 의도적 재식술을 하기 전 교 정적 정출을 가함으로써 발치를 좀더 용이하게 할 수 있 을 것으로 판단하였다. 따라서 사전에 해당 치아에 교정 력을 적용한 후 의도적 재식술을 시행하고 지르코니아 전장관 수복을 하는 것으로 치료계획을 수립하였다.

먼저 좌측 하악 제 2 대구치에 사전적 교정력을 부여하 기 위해서 본원 교정과에 협진을 의뢰하였다. 좌측 하 악 제 1 소구치, 하악 제 2 소구치, 하악 제 1 대구치의 협 면에 passive wire (dentaflex ${ }^{\circledR}, \varnothing 0.50 \mathrm{~mm}$, DENTAURUM GmbH \& Co. KG, Ispringen, Germany)를 부착 하였고 좌측 하악 제 1 대구치와 하악 제 2 대구치의 협면 에는 minitube appliance (MTA) 보다 부착력이 향상된 SNOW 브라켓(snow bracket, $2.5 \mathrm{~mm}$, KwangMyung Orthocom, Gwangju, Korea)을 부착하였다. 또한 좌측 하악 제 2 대구치의 충분한 정출 공간을 형성하기 위해 교 합면 삭제를 시행함에 따라 발생할 수 있는 대합치의 정 출을 예방하기 위해서 좌측 상악 제 1 대구치와 제 2 대구치 에도 상기의 passive wire로 레진-강선 고정을 시행하였 다(Fig. 2). 초진 사진과 3 주간 교정력을 가한 후의 치근
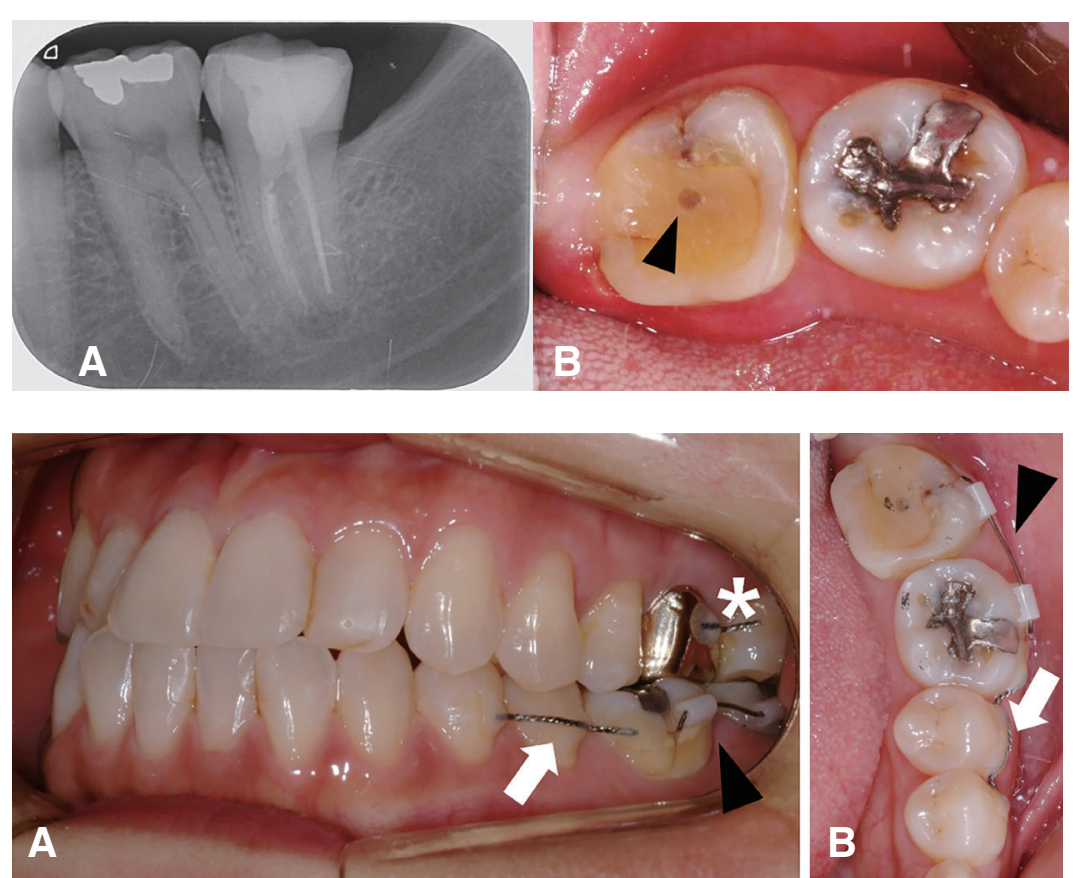

Fig. 1. (A) Preoperative radiograph of mandibular left second molar, (B) Photograph of mandibular left second molar, and cross section of fiber post exposed on occlusal surface (black arrow head).

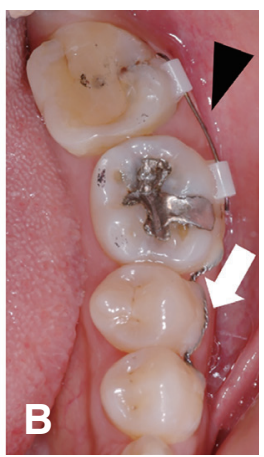

Fig. 2. Intraoral photograph of preapplication orthodontic appliance delivery. (A) SNOW bracket on \#36,37 (black arrow head), Resin wire splint (twist flex) on $\# 34,35,36$ (white arrow) and \#26,27 (asterisk), (B) Occlusal view of mandibular left second molar with SNOW bracket. 
단방사선 사진을 비교해 보면 치근단이 교합면으로 이동 한 것을 확인할 수 있으며, 3주 이후에 처음 사용한 012 NiTi 와이어(NiTi Standard 012, 0.012", Hubit, Uiwang, Korea)를 014 NiTi 와이어(NiTi Standard 014, 0.014", Hubit)로 교체하였다. 이후 추가적으로 교정력을 가하여 약 $2 \mathrm{~mm}$ 의 정출이 확인되었다(Fig. 3). 와이어를 제거하 기 전 좌측 하악 제 2 대구치는 2 도의 동요도를 보였으며 debonding 시행하였다(Fig. 4).

다음 내원에서 의도적 재식술을 시행하였다. 발치 과 정에서 치아 및 치조골, 연조직, 치주인대에 손상을 최소 화 하기 위하여 노력하였으며 발치 기자는 사용하지 않 고 발치 겸자만을 사용하였다. 발치 후 치근 표면에 다 량의 육아조직이 관찰되어 치주용 큐렛으로 제거하였다 (Fig. 5A). 치근 표면이 건조해지지 않도록 멸균된 생리식 염수를 적신 거즈로 감싸고 오염을 막기 위해 멸균된 알 루미늄 호일로 추가적으로 감싼 채 치과용 수술 현미경 (OPMI Pico; Carl Zeiss, Jena, Germany)하에서 고속핸 드피스와 다이아몬드 버를 사용하여 $3 \mathrm{~mm}$ 정도의 치근
단 절제를 시행하였고(Fig. 5B), 330번 고속핸드피스 버 로 약 $3 \mathrm{~mm}$ 깊이의 와동 형성을 시행하였다(Fig. 5C). GP cone 주변으로 제대로 충전되지 않은 빈 공간들이 확인되었다(Fig. 5D). ProRoot ${ }^{\circledR}$ white MTA (Dentsply, Tulsa, USA)를 사용하여 치근단역충전을 시행하였다. 시 술에 소요된 총 구외시간은 15 분이었다. 수술 직후에 스 테인레스 스틸 와이어(TRU-CHROME ${ }^{\circledR}$ S.S.(resilient), $.019 \times .026$, Rocky Mountain Orthodontics, Denver, USA)를 사용하여 레진-강선 고정을 시행하였고 술 후 2 주째에 재내원하여 경과관찰 후 레진-강선 고정을 제거 하였다(Fig. 6). 술후 3개월 후 지르코니아 전장관을 수복 하였고(Fig. 7A) 이후 6개월 경과 관찰 치근단 방사선 사 진 및 임상검사상 특이사항은 확인되지 않았다. 시술한 치아에 대한 타진 반응 및 동요도 없고 정상적인 치주낭 깊이를 보였으며 양호한 치은 상태를 유지 하고 있었다 (Fig. 7B). 2년 경과 관찰 시에도 환자는 큰 불편감 없이 사용하고 있었고 치근단 방사선 투과상이 감소 되었으며 치근의 흡수 소견은 관찰되지 않았다(Fig. $7 \mathrm{C}$ ).

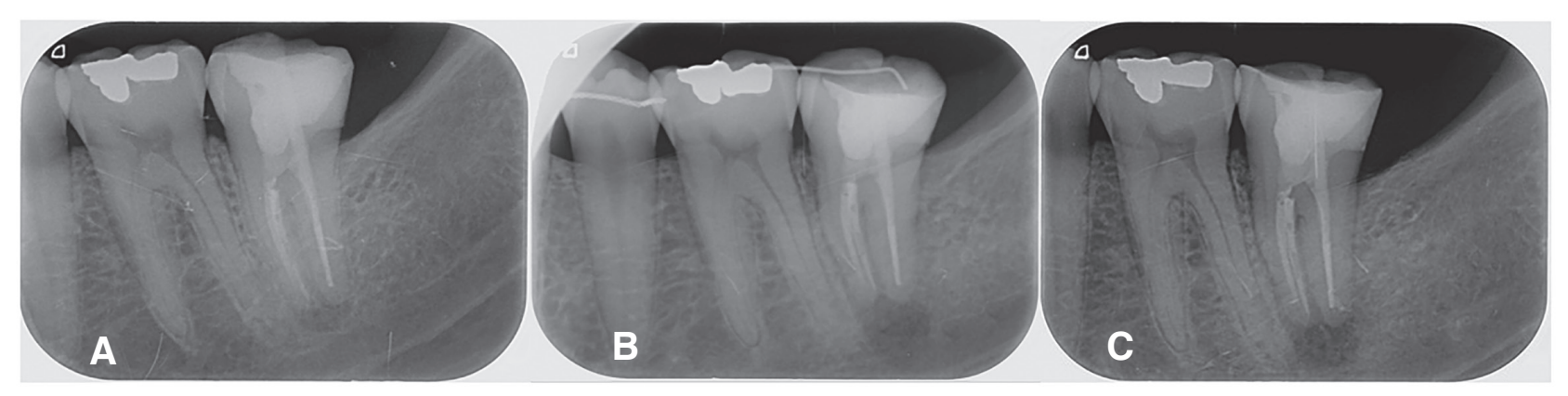

Fig. 3. Radiographs. (A) Preoperative radiograph, (B) 3 weeks follow up radiograph, (C) 3 weeks follow up radiograph after removing splinting wire and orthodontic bracket.
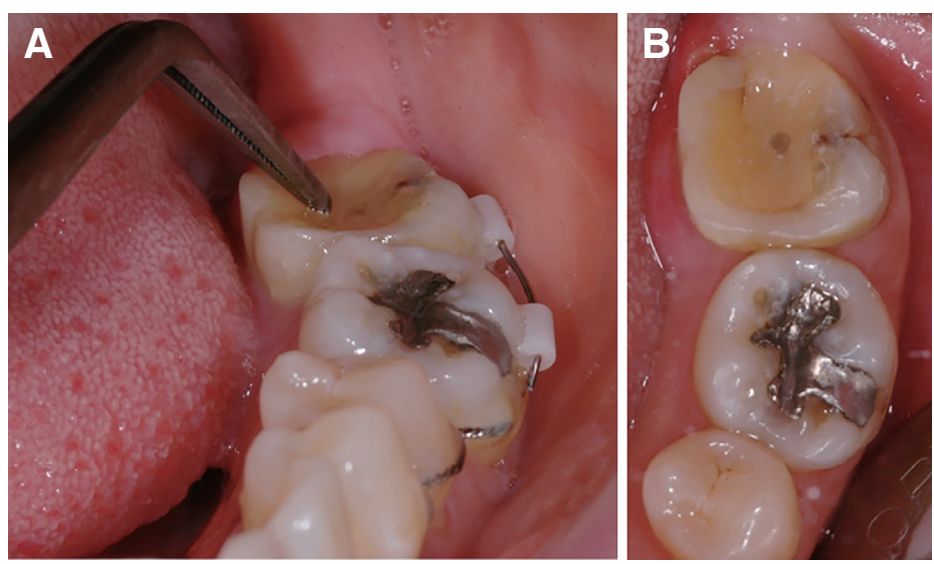

Fig. 4. Intraoral photograph of 6 weeks follow up. (A) tooth mobility test of mandibular left second molar with dental pincette, (B) Occlusal view of mandibular left second molar after removing of splinting and orthodontic appliance. 

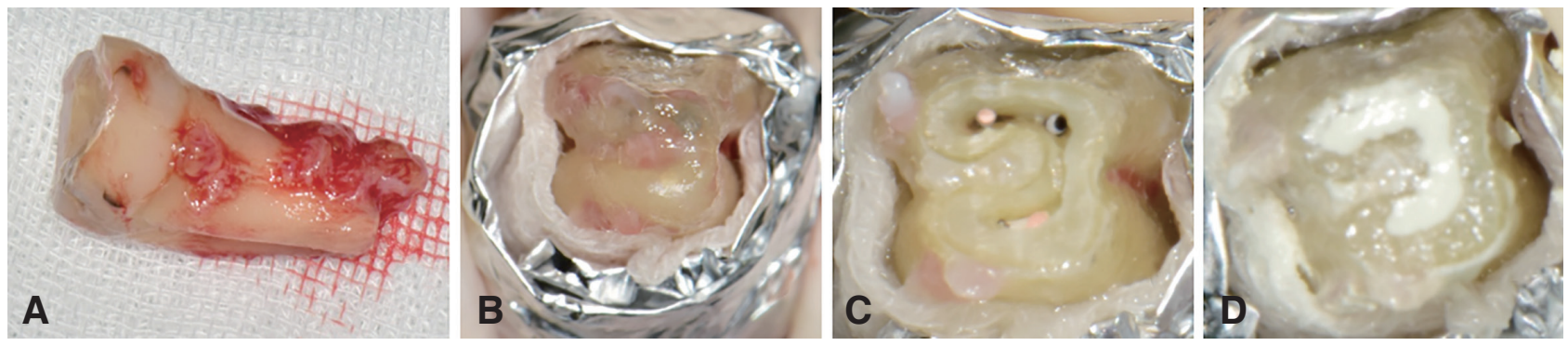

Fig. 5. Photograph of undergoing intentional replantation. (A) Extracted tooth with granuloma tissue attached on the surface of root, (B) before root-end resection. Crown and root surface is covered with sterilized aluminum foil and gauze soaked with saline solution, (C) Root-end resection and cavity preparation is finished, (D) Retrograde filling with ProRoot white MTA (Dentsply Tulsa, USA).
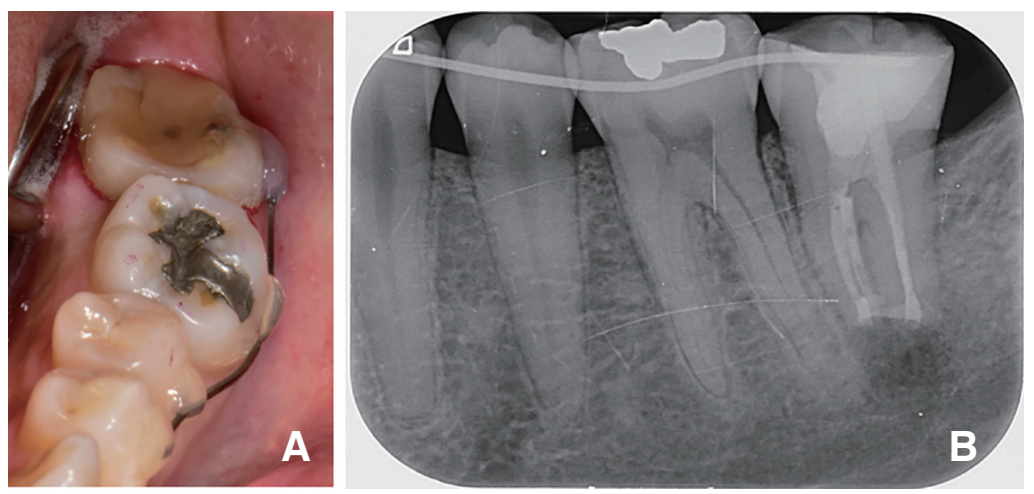

Fig. 6. 2 weeks follow up after intentional replantation. (A) Photograph of resin-wire splinting on \#34-37, (B) Radiograph of 2 weeks follow up.
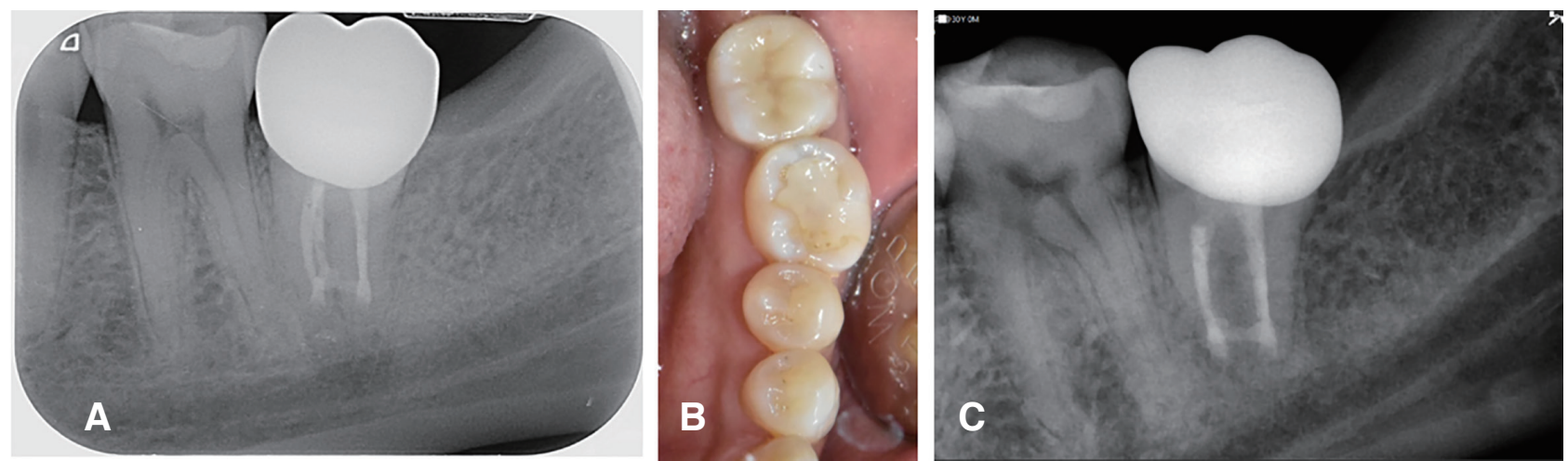

Fig. 7. (A) Radiograph of 3 month follow up after full zirconia crown setting, (B) Photograph of 3 month follow up, showing none of clinical sign, (C) Radiograph of 2 years follow up. Periapical radiolucency is decreased, and sign of root resorption is not observed.

\section{고찰}

Bender와 Rossman은 제2대구치에서 치근단 절제술에 비해 의도적 재식술이 더 유리하다고 하였는데 이는 수 술 시행이 더 용이하며 시간이 적게 걸리고 합병증이 적
으며 치근파절을 더 쉽게 발견 할 수 있기 때문이다. ${ }^{4}$ 반 면에 의도적 재식술의 주요한 실패의 원인은 치근 흡수 와 유착이다. 이는 치근 표면의 손상과 관련이 있다. ${ }^{16}$ 그 렇기 때문에 비외상성 수술법의 중요성이 강조 된다. 치 주인대 세포의 생활력을 보존하고 백악질의 손상을 예 
방하기 위해서 최소한의 치근조작이 필요하고 이를 통 해 치근 유착과 흡수를 예방할 수 있다. ${ }^{17}$ 치아 및 치주 조직의 손상을 최소화하도록 특성화된 Physics forcep ${ }^{\circledR}$ (GoldenDent, Roseville, USA)과 같은 발치 겸자를 사용 하는 것도 긍정적인 예후를 기대할 수 있는 방법이다.

본 증례에서 의도적 재식술 이후에 발치와에서 일차적 인 고정이 이루어졌으나 2주 동안 치아의 안정을 위해 레 진강선 고정을 시행하였다. 재식된 치아에서 강선의 종류 와 기간이 치주 회복에 미치는 영향에 대한 많은 연구가 이루어져왔다. ${ }^{18}$ 고정 기간 동안 사용되는 강선은 생리 적 움직임을 허용해야 하나 최근 연구에 따르면 강선의 종류가 치주 조직의 회복 과정에 영향을 미치지는 않았 다. ${ }^{18}$ 하지만, 장기간의 고정을 할 경우 치근유착과 대체 성 흡수가 관찰되었다. 따라서 이 증례에서는 이전 연구 에서 제안되었던 6 주가 아니라 2주의 치아고정을 시행하 였다. ${ }^{18}$ 또한, 의도적 재식술을 시행하는 과정에서 발치된 치아를 구강외에서 처치하는 시간을 고려해야 한다. 시 간이 길어질수록 예후는 불량하다. 특히 건조한 상태로 30 분 이상 방치된다면 재식된 치아의 생존확률이 $50 \%$ 미만인 것으로 보고되고 있다. ${ }^{19}$ 본 증례에서도 시술 시간 을 30 분이 넘지 않도록 하였으며 발치된 치아의 치근을 멸균된 생리식염수를 적신 거즈로 감싸 치주인대의 손상 을 최소화하였다.

몇몇 임상 및 실험 연구에서 재식할 치아에 사전적 기 계적 자극을 줌으로써 치주인대를 두텁게 하며 발치를 쉽게 하고 치주인대의 손상을 줄일 수 있다고 하였다. ${ }^{10,20}$ 이는 Hayashi가 자가치아이식시 교정적 정출술을 사용 하면 발치가 용이하며 치주인대의 부피가 증가하여 재식 후 신부착 또는 재부착을 촉진한다고 발표한 연구와 같 은 경향성을 나타낸다. ${ }^{21}$ 또한 Nakdilok 등의 연구에서 교정력을 4, 6, 8 주간 적용할 경우 발치에 드는 시간을 유 의미하게 줄일 수 있다는 연구 결과를 보고 한 바 있으며 이는 본 증례에서 약 6 주간의 교정력을 적용하였을 때 발 치의 용이성을 증가시킬 수 있었던 것과 같은 결과를 보 였다. ${ }^{11}$

\section{결론}

의도적 재식술은 치근흡수나 유착과 같은 부작용을 우 려하여 치아의 보존을 위한 최후의 수단으로서 고려될 것이 아니라 신뢰성 있고 예측 가능한 치료 방법으로서 적극적으로 시행될 수 있다. 또한 의도적 재식술을 시행
할 치아에 6 주간의 정출성 교정력을 부여하면 치주인대 의 폭경을 증가시켜 안전하고 더욱 용이한 발치가 이루 어질 수 있고 재식 후의 부작용을 줄여 예후를 높이는 방 법이 될 수 있다.

\section{Acknowledgements}

This study was supported by a grant (BCRI20030) Chonnam National University Hospital Biomedical Research Institute and the National Research Foundation of Korea (NRF) grant funded by the Korea government (MSIP) (No. 2019R1F1A1060935 and 2019R1A5A2027521).

\section{ORCID}

Jong-Soon Kim https://orcid.org/0000-0002-9978-5332 Hoon-Sang Chang https://orcid.org/0000-0002-3019-1528 Yun-Chan Hwang https://orcid.org/0000-0002-7891-9565

In-Nam Hwang https://orcid.org/0000-0002-5388-1919 Won-Mann Oh https://orcid.org/0000-0001-6480-6191

Bin-Na Lee https://orcid.org/0000-0001-8017-1835

\section{References}

1. Grossman LI. Intentional replantation of teeth. J Am Dent Assoc 1966;72:1111-8.

2. Grossman LI. Intentional replantation of teeth: a clinical evaluation. J Am Dent Assoc 1982;104:6339.

3. Kingsbury Jr BC, Wiesenbaugh Jr JM. Intentional replantation of mandibular premolars and molars. J Am Dent Assoc 1971;83:1053-7.

4. Bender IB, Rossman LE. Intentional replantation of endodontically treated teeth. Oral Surg Oral Med Oral Pathol 1993;76:623-30.

5. Torabinejad M, Dinsbach NA, Turman M, Handysides R, Bahjri K, White SN. Survival of intentionally replanted teeth and implant-supported single crowns: a systematic review. J Endod 2015;41:9928.

6. Frank AL, Torabinejad M. Diagnosis and treatment of extracanal invasive resorption. J Endod 1998;24: 500-4. 
7. Peer M. Intentional replantation - a 'last resort' treatment or a conventional treatment procedure? Nine case reports. Dent Traumatol 2004;20:48-55.

8. Pruthi PJ, Dharmani U, Roongta R, Talwar S. Management of external perforating root resorption by intentional replantation followed by Biodentine restoration. Dent Res J 2015;12:488-93.

9. Andreasen JO, Schwartz O, Kofoed T, DaugaardJensen J. Transplantation of premolars as an approach for replacing avulsed teeth. Pediatr Dent 2009;31:129-32.

10. Lekic P, McCulloch CA. Periodontal ligament cell populations: the central role of fibroblasts in creating a unique tissue. Anat Rec 1996;245:327-41.

11. Nakdilok K, Langsa-Ard S, Krisanaprakornkit S, Suzuki EY, Suzuki B. Enhancement of human periodontal ligament by preapplication of orthodontic loading. Am J Orthod Dentofacial Orthop 2020; 157:186-93.

12. Andreasen JO. Periodontal healing after replantation and autotransplantation of incisors in monkeys. Int J Oral Surg 1981;10:54-61.

13. Tsukiboshi M. Autotransplantation of teeth: requirements for predictable success. Dent Traumatol 2002;18:157-80.

14. Hong Q, Shigeru S, Tomio M, Masami O, Kenji S, Shoji Y, Tomohiro O, Ken-ichi Y, Yoshinobu S. Effects of pre-transplantable jiggling force on root resorption of the experimental autotransplanted of teeth in vivo. Orthod Waves 2001;60:213-25.

15. Suzaki Y, Matsumoto Y, Kanno Z, Soma K. Preapplication of orthodontic forces to the donor teeth affects periodontal healing of transplanted teeth. Angle Orthod 2008;78:495-501.

16. Kallu R, Vinckier F, Politis C, Mwalili S, Willems G. Tooth transplantations: a descriptive retrospective study. Int J Oral Maxillofac Surg 2005;34:745-55.

17. Mendes RA, Rocha G. Mandibular third molar autotransplantation-literature review with clinical cases. J Can Dent Assoc 2004;70:761-6.

18. de Andrade Veras SR, Bem JSP, de Almeida ECB, Lins CCDSA. Dental splints: types and time of immobilization post tooth avulsion. J Istanb Univ Fac Dent 2017;51:S69-75.

19. Trope M, Rosenberg ES. Multidisciplinary ap- proach to the repair of vertically fractured teeth. J Endod 1992; 18:460-3

20. Oshima H. "Nemawashi jiggling" and "Gingival muffler" in autogenous tooth transplantation. Nippon Dent Rev 1993;607: 65-74.

21. Hayashi H. Ortho-transplantation. 1st ed. Seoul; Narae Publishing Co.; 2006. p. 18-28. 


\section{하악 제2대구치의 술전 교정적 정출술을 동반한 의도적 재식술}

김종순 전공의, 장훈상 교수, 황윤찬 교수, 황인남 교수, 오원만* 교수, 이빈나* 부교수

전남대학교 치의학전문대학원 치과보존학교실

의도적 재식술은 전통적인 근관치료의 대체적 치료법으로 사용될 수 있다. 본 증례 보고에서는 기존에 근관치료 된 하악 제 2 대구치에 6 주 동안 정출성 교정력을 가한 후 해당 치아를 발거하여 치근의 처치를 시행한 후 즉각적으로 재식립하여 의도적 재식술을 수행한 증례를 보고하고자 한다. 교정력을 부여함으로서 증가된 동요도로 인해 발치의 용이성을 증가 시켰고 치주인대 폭경이 증가하여 치은 재부착을 증진 시키는 효과로 양호한 예후를 기대할 수 있었다.

(구강회복응용과학지 2021;37 (4) :274-80)

주요어: 교정력; 의도적재식술

*교신저자: 이빈나

(61186)광주광역시 북구 용봉로 77 전남대학교 치의학전문대학원 치과보존학교실

Tel: 062-530-5868 | Fax: 062-530-5629 || E-mail: bnlee13@jnu.ac. kr

*교신저자: 오원만

(61186)광주광역시 북구 용봉로 77 전남대학교 치의학전문대학원 치과보존학교실

Tel: 062-530-5572 | Fax: 062-530-5629 | E-mail: wmoh@jnu.ac. kr

접수일: 2021년 9월 15일 | 수정일: 2021년 11월 2일 | 채택일: 2021년 11월 12일

*이빈나, 오원만은 이 논문에 교신저자로 동일한 기여를 하였음. 